\title{
PENGGUNAAN QAWAID FIQHIYYAH PADA FATWA YANG DIKELUARKAN DEWAN FATWA AL JAM'IYATUL WASHLIYAH
}

\author{
Muhammad Hizbullah \\ Universitas Muslim Nusantara Al Washliyah \\ muhammadhizbullah@umnaw.ac.id
}

\begin{abstract}
Qawaid fiqhiyyah as a made to find out the content and meaning of law contained in the quran and sunnah. By being able to know ang understand qawaid fiqhiyyah we will know the common thread of fikih issues. The existence of qawaid fiqhiyyahcan be used as a meating point of fikih issues that can make wisdom in applyin the law caused of differences of time, place and tradition. The problems of Islamic law will keep on the developing based on current era. Where the publics needs a law provisio in a new problem that may not be explictly in the quran and sunnah. So an association is needed which able to answer the problemthat Al Jam,iyatil Washliyah has an organ which called Dewan Fatwa in competent to issue for a good fatwa for Al Jam'iyatul Washliyah it self although for public. Sothe article will discuss about how the method to issue and srvey the using of qawaid fiqhiyyah to Dewan Fatwa in fatwa of Al Jam'iyatul Washliyah.
\end{abstract}

\section{Keywords : Qawaid Fiqhiyyah, Dewan Fatwa, al-Jam'iyatul Washliyah}

\section{A. Pendahuluan}

Qawaid Fiqhiyyah adalah hukum syara dalam bentuk qadhiyyah (preposisi) yang bersifat dominan. Yang dengan qadhiyyah tersebut dapat diketahui ketentuan hukum mengenai peristiwa-peristiwa hukum yang berada di dalam ruang lingkupnya. ${ }^{1}$ Dapat dipahami qawaid fiqhiyyah pada hakikatnya merupakan sekumpulan kaidah-kaidah fikih yang berbentuk rumusan-rumusan yang bersifat umum dan di dalamnya terkandung ketentuan-ketentuan hukum fikih dalam berbagai bidang yang termasuk dalam ruang lingkupnya. ${ }^{2}$

Pentingnya pemahaman dalam qawaid fiqhiyyah yang merupakan asas atau mekanisme dalam ilmu fikih yang perlu diketahui secara umum oleh umat Islam, terutama bagi para mujtahid karena berkaitan dengan pengistinbatan hukum. Dengan qawaid fiqhiyyah yang merupakan hasil ijtihad para ulama, maka hal yang wajar jika antara kaidah yang satu dengan kaidah yang lainnya memiliki perbedaan. Karenanya banyak kaidah fiqhiyyah yang berkembang mulai dari dari keberadaan kaidah asasiyah, kaidah ghairu asasiyah bahkan kaidah yang masih diperselisihkan di kalangan ulama.

1 Ali ahmad an-Nadawi, Al-Qawaid al fiqhiyyah Mafhumuha Nasyatuha Tathawwuruha (Damsyiq: dar al-qalam, 1986), hal. 43.

2 Abd. Rahman Dahlan, Ushul Fiqh (Jakarta : Amzah, 2010), hal. 15. 
Al Washliyah merupakan ormas yang berdiri di Sumatera Utara. Sebagai organisasi kemasyarakatan yang memiliki Dewan Fatwa yang disebut dengan Dewan Fatwa Al Washliyah memiliki fungsi dan wewenang untuk memberikan fatwa sebagai pedoman penyelesaian persoalan-persoalan organisasi dalam bidang hukum serta keorganisasian. Dewan fatwa diharapkan mampu memberikan solusi dan jawaban pada permasalahan-permasalahan hukum Islam yang terjadi di tengah-tengah masyarakat. Dengan kondisi permasalahan yang semakin kompleks dan terus berkembang diperlukan pemikiran/ijtihad dan metode dalam pengistinbatkan hukum agar dapat menghasilkan suatu hukum yang baik dan benar.

\section{B. Sejarah Al jam'iyatul Washiyah dan Dewan Fatwa}

1. Al Jam'iyatul Washliyah

Al Jam'iyatul Washliyah lahir dalam masa tertindas oleh penjajah Belanda yang sedang berkuasa. Organisasi ini lahir pada tanggal 30 Nopember 1930 bertepatan dengan 9 Rajab 1439 H. Hal ini juga diumumkan secara resmi dalam surat-surat kabar termasuk pada Pewarta Deli. ${ }^{3}$ Al Jam'iyatul Washliyah bermazhab Syafii, dengan kondisi masyarakat pada waktu itu yang menyata kan diri mereka bermazhab Syafii secara antusias mendukung Al Jam'iyatul Washliyah. ${ }^{4}$

Anggaran Dasar Al Jam'iyatul Washliyah dalam penginstinbatan hukum disempurnakan dari awalnya bermazhab/beraliran Syafii menjadi iktikad dan bermazhab Ahlussunnah wal Jamaah dengan tetapkan mengedepankan mazhab Syafii. ${ }^{5}$ Dorongan awal mendirikan organisasi ini ketika itu didasari ingin mempersatukan umat yang berbeda pandangan, yang ditunggangi oleh penjajah serta ingin mewujudkan cita-cita bangsa menjadi negara yang merdeka. ${ }^{6}$ Ini dapat dilihat dari keterlibatan para pengurus dan anggotanya dalam pengupayaan kemerdekaan Republik Indonesia.

Upaya memecah belah rakyat terus merasuk hingga ke sendi-sendi agama Islam. Umat Islam saat itu dapat dipecah belah disebabkan oleh perbedaan pandangan dalam hal ibadah dan cabang dari agama (furu'iyah). Kondisi ini terus meruncing, hingga umat Islam terbagi menjadi dua kelompok yang disebut dengan kaum tua dan kaum muda. Perbedaan paham dibidang agama ini semakin hari semakin meruncing bahkan sampai pada tahap yang amat meresahkan.

Dengan terjadinya persilisihan pada umat Islam di Sumatera Utara terkhusus kota medan, para murid yang belajar di Maktab Islamiyah Tapanuli (MIT) Medan berusaha menyatukan kembali umat yang terpecah belah saat itu. Upaya dalam menyatukan umat Islam terus dilakukan yang

\footnotetext{
3 Ja'far, Al-Jam'iyatul Washliyah Potret Histori, Edukasi dan Filosofi (Medan: Perdana Publishing, 2011), hal. 7.

${ }^{4}$ Nina M. Armandi Nina, Ensikloped Islam.( Jakarta : Ichtiar Baru van Hoeve, 2005), hal. 293.

5 Dewan Fatwa Al-Jam‘iyatul Washliyah, Laporan Hasil-Hasil Sidang Dewan Fatwa Al-Jam 'iyatul Washliyah (Medan, Universitas Muslim Nusantara, 1998), hal. 1-2.

${ }^{6}$ Ahmad Hamim Azizy, Al-Jam'iyatul Washliyah dalam Kancah Politik Islam (Banda Aceh : Yayasan Pena, 2006), hal. 65.
} 
mewujudkan terbentuklah organisasi Al Jam'iyatul Washliyah yang artinya perkumpulan yang menghubungkan.

dari:

Susunan Kepengurusan Al Jam'iyatul Alwashliyah yang pertama terdiri

Penasehat : Syekh H. Muhammad Yunus

Ketua I : Ismail Banda

Ketua II $\quad:$ H. Abdurrahman Syihab

Sekretaris I : H. Muhammad Arsyad Thalib Lubis

Sekretaris II : Adnan Nur

Bendahara : M. Ya'cub

Pembantu-Pembantu : H. Syamsuddin

H. A. Malik

H. Yusuf Ahmad Lubis

Abdul Aziz Effendi

\section{Dewan Fatwa}

Dewan Fatwa merupakan badan kemusyawaratan ulama dan cendekiawan Al Jam'iyatul Washliyah yang berfungsi dan berwenang memberikan fatwa sebagai pedoman penyelesaian persoalan-persoalan organisasi dalam bidang hukum dan keorganisasian. ${ }^{7}$ Dewan Fatwa ini bermula bernama Majelis Fatwa dan berganti nama menjadi Dewan Fatwa Penasehat \& Pertimbangan pada pelaksanaan muktamar Al Jam'iyatul Washliyah ke-16 di Jakarta tanggal 20 sampai dengan 24 Pebruari $1986 .{ }^{8}$

Al Jam'iyatul Washliyah membentuk Majelis Fatwa tepatnya di tanggal 10 Desember 1933. ${ }^{9}$ Para ulama Al Jam'iyatul Washliyah mengeluarkan fatwa secara kolektif dengan anggota majelis. Majelis Fatwa memiliki fungsi mengeluargan fatwa keagamaan kepada anggota Al Jam'iyatul Washliyah dan masyarakat umum. Selain itu berfungsi sebagai pembinaan kader ulama dalam mengeluarkan fatwa mengenai masalah keagamaan. .

Menurut Al Jam'iyatul Washliyah Ijtihad yang memiliki kompetensi dalam mengeluarkan fatwa dalam penetapan suatu hukum adalah ulama-ulama terdahulu, karena tidak semua orang mempunyai kesanggupan mengeluarkan hukum dengan seorang diri dari alquran dan sunnah, karena untuk melaksanakan pekerjaan tersebut harus memenuhi berbagai persyaratan. Harus mengerti benar bahasa Arab, mempunyai perlengkapan tentang ilmu-ilmu yang diperlukan untuk memahami alquran dan sunnah, dan berbagai syarat lain yang diterangkan dalam kitab Usul Fikih. Pada prinsipnya organisasi ini tidak menolak ijtihad, akan tetapi karena belum mampu mencapai taraf penguasaan dan pendalam ilmu, karena sebagian besar para pendukung organisasi ini masih dalam taraf

\footnotetext{
${ }^{7}$ Pengurus Besar Al Jam'iyatul Washliyah, Anggaran Dasar dan Anggaran Rumah Tanggal Al Jam 'iyatul Wahliyah Periode 2003-2008 (Jakarta: PB. Alwashliyah, 2003) hal. 11.

${ }^{8}$ M. Hasbullah Thaib, Universitas Al Washliyah Medan Lembaga Pengkaderan Ulama Di Sumatera Utara (Medan : Universitas Al Washliyah, 1993) hal. 56.

${ }^{9}$ Chalidjah Hasanudin, Al-Jam'iyatul Washliyah 1930-1942 Api dalam Sekam di Sumatera Timur (Bandung: Pustaka, 1998), hal. 105.
} 
belajar, yang harapannya dengan adanya majelis ini muncul kader ulama di kalangan Al Jam'iyatul Washliyah.

Mengikuti anggaran dasar Al Washliyah pada muktamarnya yang ke-18 menyebutkan: dalam penginstinbatan hukum disempurnakan dari bermazhab/beraliran Syafii menjadi dalam iktikad bermazhab Ahlussunnah wal Jama'ah dengan mengedepankan mazhab Syafii. ${ }^{10}$ Arti bermazhab Syafii yang termaktub pada anggaran dasar Al Jam'iyatul Washliyah adalah:

a. Ruang lingkup fikih mazhab syafii dijadikan rujukan dalam setiap permasalahan yang dibahas pada organisasi Al Jam'iyatul Washliyah.

b. Mengedepankan mazhab syafii dalam pemutusan persoalan dan perselisihan hukum fikih yang terjadi pada organisasi Al Jam'iyatul Washliyah.

Statement ini bertujuan menunjukan ketegasan dan penguatan pada penetapan permasalahan hukum Islam, agar terhindar dari kesalahpahaman dalam upaya menyatukan paham dan memperjuangkan kepentingan umat Islam. ${ }^{11}$ Mengedepankan dan mengutamakan mazhab Syafii bukan berarti menutup kemungkinan dan melakukan pembatasan anggotanya untuk mengadopsi pendapat mazhab lain, selama hal itu dilakukan dalam ruang lingkup kepentingan pribadi.Al Jam'iyatul Washliyah memberikan kebebasan dalam menjalankan perkara amaliyah sesuai dengan keyakinan bermazhabnya akan tetapi jika mengatasnamakan organisasi maka harus mengutamakan dan mengedepankan mazhab syafii.

Berdasarkan anggaran dasar tahun 2003-2008 Dewan Fatwa Penasehat dan Pertimbangan, dibagi menjadi dua, yaitu: Dewan Fatwa dan Dewan Penasehat dan Pertimbangan. Berdasarkan AD/ART Al Jam'iyatul Washliyah tahun 2003 - 2008 menyebutkan tentang ketentuan Dewan Fatwa pada Bab VI, pasal 11, dan yang berhubungan dengan putusan fatwanya, yaitu:

a. Dewan Fatwa adalah badan permusyawaratan ulama dan cendikiawan Al Washliyah yang berfungsi dan berwenang memberi fatwa sebagai pedoman penyelesaian persoalan-persoalan organisasi dalam bidang hukum dan keorganisasi.

b. Dalam pelaksanaan fungsi sebagaimana dimaksud pada pasal 11 ayat (1) Dewan Fatwa berhak memutuskan sesuatu hukum dan penyelesaian persoalan-persoalan yang timbul dikalangan Al Washliyah.

c. Pengurus Besar wajib melaksanakan keputusan-keputusan sebagaimana dimaksud pada pasal 11 ayat (4) di atas. ${ }^{12}$

Dari keterangan tersebut menunjukkan Dewan Fatwa Al Jam'iyatul Washliyah merupakan bagian penting dalam organisasi ini. Karena memiliki fungsi dan kontribusi yang signifikan dalam mengeluarkan fatwa

\footnotetext{
${ }^{10}$ Dewan Fatwa, Laporan Hasil-Hasil Sidang, hal. 1-2.

11 Tim Pelaksana Proyek Penulisan Buku 70 Tahun Al-Washliyah, Al Jam 'iyatul Washliyah Memasuki Millenium II Kado Ulang Tahun A-lwashliyah ke-69 Tahun 1999 (Jakarta : PB Al Washliyah, 1999), hal. 55.

12 Pengurus Besar , Anggaran Dasar, hal. 11.
} 
terhadap permasalahan hukum Islam yang timbul di kalangan $\mathrm{Al}$ Jam'iyatul Washliyah maupun kalangan masyarakat luas.

\section{Sistematika Fatwa Pada Dewan Fatwa Al Jam'iyatul Washliyah}

Anggaran Dasar Al Jam'iyatul Washliyah menyatakan bermazhab Syafii dengan berakidah Ahlussunnah wal jama'ah, hal ini yang menyebabkan dengan cepat mendapat dukungan dari masyarakat luas, karena masyarakat pada waktu itu mayoritas bermazhab Syafii. Pada anggaran Dasar Al Jam'iyatul Washliyah juga menyatakan dalam fikih disempurnakan dari bermazhab Syafii menjadi dalam iktikad dalam bermazhab Ahlus Sunnah wal Jama'ah dengan tetap mengutamakan mazhab Syafii. Atas dasar ini, Pedoman Penetapan Fatwa Al Jam'iyatul Washliyah diformulasikan sebagai berikut:

a. Fatwa harus berdasarkan kepada salah satu dalil hukum Islam, yaitu Alquran, Sunnah, ijmā', qiyās, al-istiḥsān, maṣlaḥ ah mursalah, al-'urf, al-istishab, syar'u man qablana.

b. Fatwa dengan metode istinbāt yang digunakan para ulama mazhab dari kalangan Ahlussunnah wal jama 'ah.

c. Fatwa yang dikeluarkan oleh Dewan Fatwa adalah menurut mazhab Syafii dalam kitab-kitab mu'tabarah dengan ketentuan di bawah ini:

1. Dalam permasalahan yang ketentuannya hanya didapatkan satu qaul/wajah pada kitab yang 'ibarah, fatwa ditetapkan menurut qaul/wajah tersebut.

2. Dalam permasalahan yang ketentuannya ditemukan lebih daripada satu qaul/wajah pada kitab 'ibarah dengan, fatwa ditetapkan menurut hirarki sebagai berikut: ${ }^{13}$

(a) Pendapat yang disepakati oleh An-Nawawi dan Ar-Rafi'i. (b) Pendapat yang ditetapkan oleh An-Nawawi saja, (c) Pendapat yang ditetapkan oleh Ar-Rafi'i saja, (d) Pendapat yang kuat dari mayoritas ulama. , (e) Pendapat yang kuat oleh ulama yang dianggap terpintar/meguasi, (f) Pendapat yang kuat oleh ulama yang paling warak.

3. Mengenai kasus atau masalah yang ketentuan hukumnya tidak ditemukan dalam kitab, fatwa ditetapkan melalui ilhāq masalah kepada nazirnya.

4. Mengenai kasus atau masalah yang hukumnya dalam mazhab Syafii dalam kondisi tertentu, ta 'azzur atau ta 'assur untuk diamalkan, fatwa dapat ditetapkan dengan melakukan ikhtiyar terhadap salah satu qaul/pendapat dalam mazhab Syafii atau pendapat mazhab di luar Syafii dari kalangan Ahlussunnah wal jama'ah.

5. Mengenai kasus atau masalah yang ketentuan hukumnya tidak ditemukan dalam kitab dan tidak mungkin dilakukan ilhaq, fatwa ditetapkan melalui ijtihad jama' $i{ }^{14}$

Dalam mengamalkan ta'azzur atau ta'assur (sulit atau sukar) untuk diamalkan, fatwa dapat ditetapkan dengan melakukan ikhtiyar terhadap

${ }^{13}$ Syaid Abu Bakar Alma'syur, I'anath Ath Thalibin (Mekkah : Dar Ihya Al Kutub Arabiyah, tt), Juz 1, hal. 19.

${ }^{14}$ Dewan Fatwa, Laporan Hasil-Hasil Sidang, hal. 1-2. 
salah satu qaul/pendapat dalam mazhab Syafii atau pendapat mazhab di luar Syafii dari kalangan Ahlussunnah wal jama 'ah.

\section{Survey Qawaid Fiqhiyyah Pada Dewan Fatwa Al Jam'iyatul Washliyah}

Fatwa-fatwa yang dijadikan sampel dalam makalah ini didapatkan langsung dari Dewan Fatwa Aljam'iyatul Washliyah. Tiga fatwa yang dikeluarkan Dewan Fatwa Al Washliyah memuat lima bagian, yaitu mendengar, memperhatikan, menimbang, mengingat dan memfatwakan. Dalil yang diawali dengan ayat suci alquran, sunnah, pendapat imam syafii/mazhab syafii serta memapakarkan qawaid Fiqhiyyah dalam bagian ke mengingat pada surat keputusan dewan fatwa. Dan tidak semua fatwa yang dikeluarkan Dewan Fatwa Menggunakan qawaid fiqhiyyah karena jika sudah cukup jelas dan kuat dari dalil alquran dan sunnah maka fatwa tidak akan menggunakan qawaid fiqhiyyah.

\section{Keputusan Dewan Fatwa PB Aljam'iyatul Washliyah Nomor : 01/Kep./df-AW/V/2016 Tentang Hukum Membunyikan Petasan}

Fatwa keharaman membunyikan petesan yang dikeluarkan oleh Dewan Fatwa Al Jam'iyatul Washliyah dengan alasan banyaknya masyarakat yang membunyikan petasan, baik di bulan Ramadan, penyambutan tahun baru, dan even lainnya Dengan demikian dewan fatwa Al Jam'iatul Washliyah merekomendasikan supaya umat Islam tidak ikut menjual petesan, serta kepada orang tua untuk tidak memberi izin serta membiarkan anak-anaknya untuk membeli dan bermain petasan. Kepada para Ustaz/Ustazah/Pemuka Masyarakat untuk mensosialisasikan fatwa ini kepada masyarakat. Dan diiminta kepada pihak pemerintah yang berwenang dan kepolisian untuk menertibkan dan menindak tegas pelaku yang membunyikan dan menjual petasan demi terciptanya kondisi masyarakat yang kondusif.

Pengharaman membunyikan petasan/mercon menurut Dewan Fatwa Al Jam'iyatul Washliyah dikarenakan mercon/petasan bukan berasal dari Islam, melainkan budaya bangsa Cina yang berasal dari Tiongkok sekitar abad ke-09 dengan mencampur tiga bahan: belerang (sulfur), arang kayu (charcoal), dan bubuk hitam (black powder) yang dibakar sampai meledak dan dipercaya untuk mengusir roh jahat. Keberadaan petasan pertama kali diperkenalkan oleh seorang pendeta Cina bernama Li Tian pada masa Dinasti Song (960-1279 M).

Banyaknya kemafsadatan/kerusakan akibat petasan, antara lain:

a. Membakar petasan di waktu malam, terutama pada bulan Ramadan jelas mengganggu orang yang sedang beribadah, mengganggu orang yang sedang tidur, dan mengganggu kesehatan orang yang sakit jantung.

b. Terbakarnya lima pintu rumah kontrakan milik Gidion, di Lebak Pasar Kelurahan Babakan Pasar Kota Bogor, Jawa Barat pada pukul 18.00 WIB

c. Tewasnya Gilang Azwani pemuda berusia 23 tahun akibat petasan pada malam pergantian tahun baru di Batam, Kepulauan Riau, pada Jumat 01 Januari 2016. (Liputan6.com, Batam).

Dalil-dalil pengharaman membunyikan mercon/petasan

1. Alquran

Petasan merupakan bentuk kepercayaan bangsa Cina. Dalam sejarah petasan memiliki nuansa teologis sebagai sesuatu yang dapat mengusir roh jahat. Sementara, Islam melarang kepercayaan khurafat.

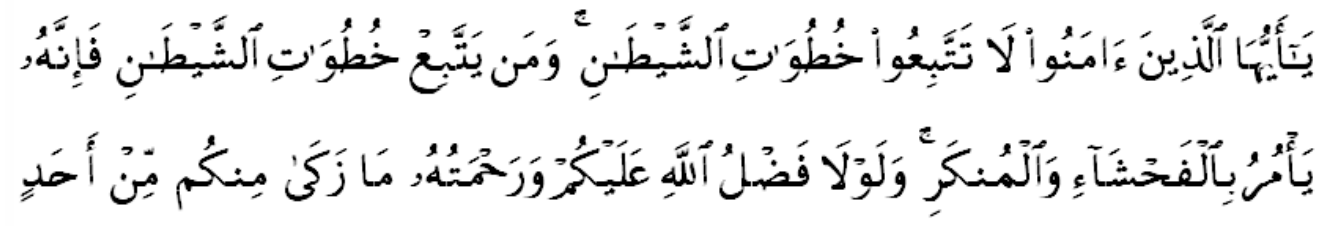


Artinya : Wahai orang-orang yang beriman, janganlah kamu mengikuti langkah- langkah setan. Barangsiapa yang mengikuti langkah-langkah setan, Maka Sesungguhnya dia (setan) menyuruh mengerjakan perbuatan yang keji dan yang mungkar. Kalau bukan karena kurnia Allah dan rahmat-Nya kepadamu, niscaya tidak seorangpun di antara kamu bersih (dari perbuatan keji dan mungkar itu) selama-lamanya, tetapi Allah membersihkan siapa yang Dia kehendaki. Dan Allah Maha mendengar, Maha mengetahui. ${ }^{15}$

2. Hadis yaitu membakar petasan dapat mengganggu ketenteraman orang lain dan sering menimbulkan kemudratan seperti kebakaran, luka-luka, bahkan meninggal dunia.

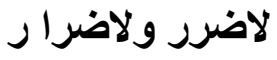

"(Kamu) tidak boleh membuat bahaya dirimu sendiri dan tidak boleh membuat bahaya bagi orang lain".

3. Qawaid fiqhiyyah yaitu Bahwa menurut data-data yang dihimpun, petasan sudah terbukti menimbulkan kemudratan/kerusakan. Kaidah fikih menyatakan bahwa kemudratan itu harus dihilangkan.

$$
\text { الضرر يزال }
$$

2. Keputusan Dewan Fatwa PB Aljam'iyatul Washliyah Nomor : 26 /Kep./df-AW/XI/2016 Tentang Hukum Salat Jumat Dilaksanakan di Jalan Raya, Lapangan, Tempat Terbuka yang Bukan Mesjid

Dewan Fatwa memfatwakan dengan kondisi tertentu sah salat Jumat di jalan raya, lapangan, tempat terbuka, dan yang bukan masjid. Serta dalam kondisi tertentu, sah salat Jumat meskipun jumlah jemaahnya tidak mencapai empat puluh (40) orang. Dengan dalil-dalil :

1. Alquran

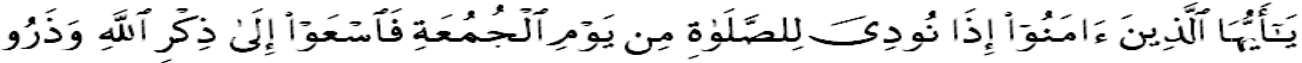

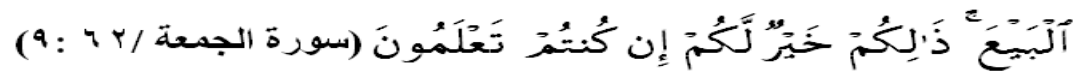

Artinya : Wahai orang-orang beriman, apabila telah diseru untuk melaksanakan salat Jum'at, Maka segeralah kamu mengingat Allah dan tinggalkanlah jual beli, yang demikian itu lebih baik bagimu jika kamu mengetahui. ${ }^{16}$

2. Hadis yang diriwayatkan Abu daud

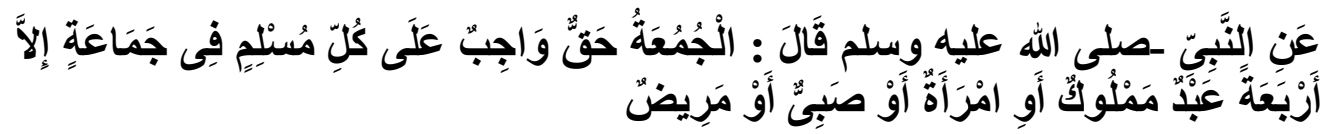

15 Departemen Agama RI, Al-Qur'an Dan Terjemahnya (Jakarta : CV. Pustaka Agung, 2006), hal. 491.

${ }^{16}$ Departemen Agama RI, Al-Qur'an Dan, hal. 809. 
Artinya : "Bahwa Nabi sallahu alaihi wassalam bersabda, " Salat Jumat adalah suatu kewajiban atas setiap orang Islam yang harus dilaksanakan secara berjemaah, terkecuali terhadap empat orang budak, wanita, anak kecil dan orang yang dalam keadaan sakit.

Dan hadis lain yang diriwayatkan ibnu hibban

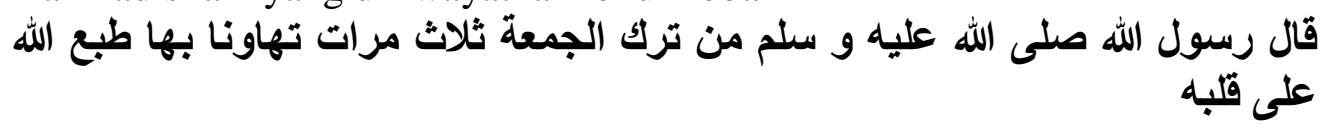

Artinya : Siapa yang meninggalkan salat Jumat tiga kali berturut-turut karena meremehkannya, maka Allah akan menutup pintu hatinya". (HR. Ibnu Hibban).

3. Pendapat Ulama

Pendapat Imam as-Syafii yang dinukil Imam an-Nawawi bahwa salah satu pendapat membolehkan (sah) salat Jumat yang dilaksanakan oleh penduduk tidak tetap:

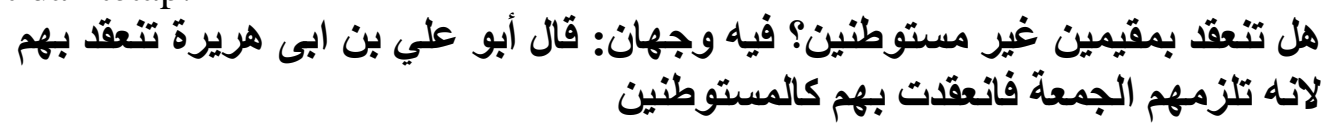

Apakah sah salat Jumat yang dilaksanakan orang yang bukan penduduk tetap (muqimin)? Mengenai hal ini ada dua pendapat: Abu Ali ibn Abi Hurairah berpendapat salat Jumatnya sah, oleh karena mereka adalah orang yang diwajibkan atas mereka Jumat sebagaimana yang dilaksanakan oleh penduduk tetap

Dan Sayyid Abd ar-Rahman ibn Muhammad ibn Husain ibn Umar menyebutkan

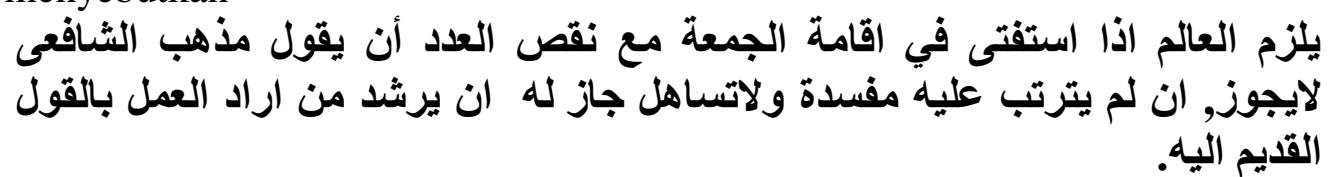

Wajib bagi orang yang alim, ketika diminta fatwa dalam masalah mendirikan salat Jumat yang didirikan oleh jemaah yang kurang dari empat puluh orang, hendaknya dia menjawab, "Menurut mazhab as-Syafii hukumnya tidak boleh." Akan tetapi, jika tidak menimbulkan mafsadah (dampak negatif) atau meremehkan, maka boleh baginya untuk memberitahukan kepada orang yang menginginkan mengamalkan qaul qadim (Imam as-Syafii) yang memperbolehkannya.

4. Kaidah fikih

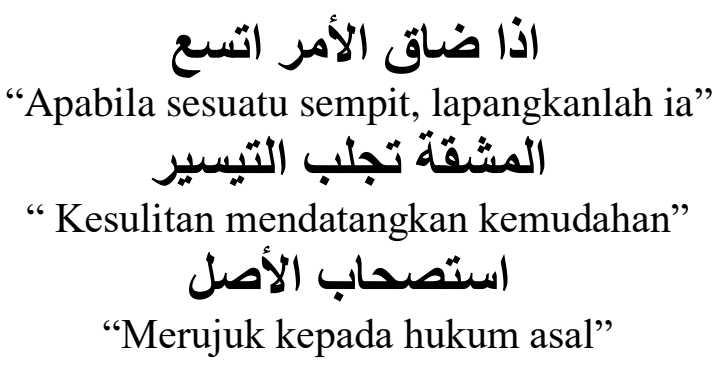

3. Keputusan Dewan Fatwa PB Aljam'iyatul Washliyah Nomor : 02 /Kep./df-AW/XI/2016 Tentang Tradisi Asmara Subuh/Khalwat/Pacaran di Bulan Suci Ramadan

Fatwa ini dikeluarkan oleh Dewan Fatwa Al Jam'iyatul Washliyah dikarenakan maraknya dan semakin meluasnya tradisi asmara subuh. dimana remaja Islam di Indonesia memadu kasih berpacaran selepas sahur di jalanan di 
bulan Ramadan,. Dewan Fatwa memfatwakan tradisi asmara subuh/khalwat/pacaran, terutama di bulan Ramadan adalah haram. Dengan dalildalil sebagai berikut :

1. Alquran

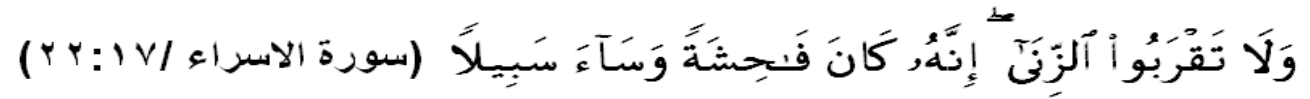

Artinya : Dan janganlah kamu mendekati zina; Sesungguhnya zina itu adalah suatu perbuatan yang keji. dan suatu jalan yang buruk.

2. Hadis Sahih Imam Muslim No. 2391

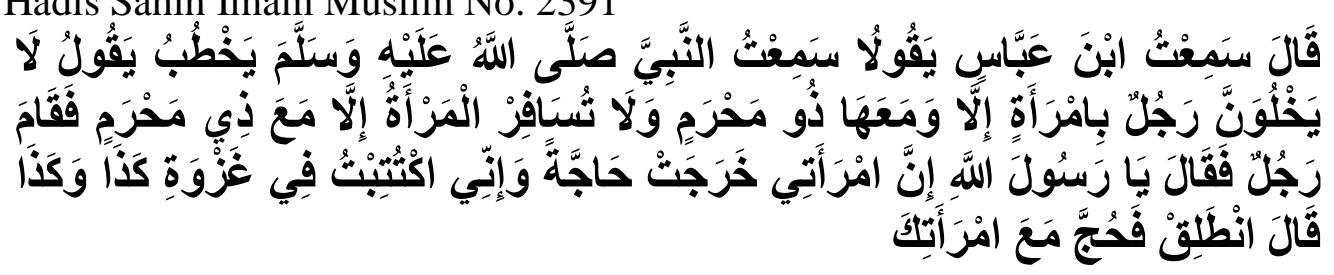

Artinya : Ibnu Abbas berkata, "Saya mendengar Nabi sallahu alaihi wassalam. berkhutbah seraya bersabda, "Janganlah sekali-kali seorang laki-laki berduaan dengan seorang wanita kecuali wanita itu disertai mahram-nya. Dan seorang wanita juga tidak boleh bepergian sendirian, kecuali ditemani oleh mahram-nya. Tiba-tiba berdirilah seorang laki-laki dan bertanya, "Ya, Rasulullah, sesungguhnya isteriku hendak menunaikan ibadah haji, sedangkan aku ditugaskan pergi berperang ke sana dan ke situ; bagaimana itu?" Rasulullah saw. pun menjawab, "Pergilah kamu haji bersama isterimu" (HR. Muslim)

\section{KESIMPULAN}

Dewan Fatwa merupakan badan kemusyawaratan ulama dan cendekiawan Al Jam'iyatul Washliyah yang berfungsi dan berwenang memberikan fatwa sebagai pedoman penyelesaian persoalan-persoalan organisasi dalam bidang hukum dan keorganisasian.

Pedoman Penetapan Fatwa Al Jam'iyatul Washliyah Fatwa harus berdasarkan kepada salah satu dalil hukum Islam, yaitu Alquran, Sunnah, ijma; qiyas, al-istihsan, maslah ah mursalah, al-'urf, al-istishab dan syar'u man qablana. Metode yang digunakan dalam menetapkan fatwa adalah metode istinbat yang digunakan para ulama mazhab dari kalangan Ahlussunnah wal jama'ah.

Fatwa yang dikeluarkan Dewan Fatwa Al Jam'iyatul Washliyah memuat lima bagian, yaitu mendengar, memperhatikan, menimbang, mengingat dan memfatwakan. Dengan menggunakan dalil yang diawali dengan ayat suci alquran, hadis, pendapat imam syafii/mazhab syafii serta qawaid Fiqhiyyah. Survey penggunaan qawaid fiqhiyyah pada fatwa yang dikeluarkan Dewan Fatwa Al Jam'iyatul Washliyah digunakan walaupun tidak semua fatwa menggunakan qawaid fiqhiyyah dikarenakan sudah jelas hukumnya melalui alquran dan sunnah. 


\section{DAFTAR PUSTAKA}

Abd. Rahman Dahlan, Ushul Fiqh (Jakarta : Amzah, 2010)

Ahmad Hamim Azizy, Al-Jam'iyatul Washliyah dalam Kancah Politik Islam (Banda Aceh : Yayasan Pena, 2006)

Ali ahmad an-Nadawi, Al-Qawa<id al fiqhiyyah Mafhumuha Nasyatuha Tathawwuruha (Damsyiq: dar al-qalam, 1986)

Chalidjah Hasanudin, Al-Jam'iyatul Washliyah 1930-1942 Api dalam Sekam di Sumatera Timur (Bandung: Pustaka, 1998)

Dewan Fatwa Al-Jam'iyatul Washliyah, Laporan Hasil-Hasil Sidang Dewan Fatwa Al-Jam 'iyatul Washliyah (Medan, Universitas Muslim Nusantara, 1998)

Departemen Agama RI, Al-Qur'an Dan Terjemahnya (Jakarta : CV. Pustaka Agung, 2006)

Ja'far, Al-Jam'iyatul Washliyah Potret Histori, Edukasi dan Filosofi (Medan: Perdana Publishing, 2011)

M. Hasbullah Thaib, Universitas Al Washliyah Medan Lembaga Pengkaderan Ulama Di Sumatera Utara (Medan : Universitas Al Washliyah, 1993)

Nina M. Armandi Nina, Ensiklopedi Islam.( Jakarta,:Ichtiar Baru van Hoeve, 2005)

Pengurus Besar Al Jam'iyatul Washliyah, Anggaran Dasar dan Anggaran Rumah Tanggal Al Jam iyatul Wahliyah Periode 2003-2008 (Jakarta: PB. Alwashliyah, 2003)

Syaid Abu Bakar Alma'syur, I'anath Ath Thalibin (Mekkah : Dar Ihya Al Kutub Arabiyah, tt)

Tim Pelaksana Proyek Penulisan Buku 70 Tahun Al-Washliyah, Al Jam'iyatul Washliyah Memasuki Millenium II Kado Ulang Tahu Alwashliyah ke-69 Tahun 1999 (Jakarta : PB Al Washliyah, 1999) 
